\title{
First report of Curvularia leaf spot of Chamaedorea seifrizii caused by Curvularia lunata in Pakistan
}

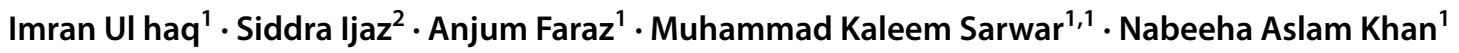

Received: 17 November 2020 / Accepted: 26 February 2021 / Published online: 4 March 2021

(c) Società Italiana di Patologia Vegetale (S.I.Pa.V.) 2021

Keywords Ornamental Palm · Leaf spots disease $\cdot$ Molecular identification $\cdot$ Curvularia lunata

Chamaedorea seifrizii Burret (Seifriz's chamaedorea) is shade loving indoor ornamental plant. During 2015-2016, leaf spot disease (dark brown spots with yellow margins) was observed in Faisalabad, Lahore, Kasur and Islamabad Districts with disease incidence of 55, 37, 48 and 39\%, respectively. Upon maturity, spots enlarged with round to elliptical irregular shape, coalesced, leaves turned grey and died. Symptomatic leaves were surface disinfected with $2 \%$ sodium hypochlorite solution, excised into segments and placed on potato dextrose agar (PDA) culture medium. Colonies were purified with single spore technique. Whitish to greyish black mycelial growth was observed after 8 days of incubation at $26^{\circ} \mathrm{C}$. Colonies were blackish, conidiophores were septate with dark brown scars, unbranched, and flexuose at apical region. Conidia were dark brown, boat shaped with rounded tips, smooth walled, in sympodial order and $25-33 \times 12-14 \mu \mathrm{m}$ size (Manamgoda et al. 2012). Based on macro- and micro-morphological features of colonies, the fungus was identified as Curvularia lunata (Wakker) Boedijn. Morphological identification was supported by molecular analysis of internal transcribed spacer (ITS) region, RNA polymerase II second largest subunit (RPB2) and glyceraldehyde 3-phosphate dehydrogenase (GAPDH). BLASTn analysis revealed $100 \%$ homology to the strain CBS 730.96 Curvularia lunata. The reference sequences were submitted to GenBank (Accession Nos. MN971669, MN972618 and MN972620, respectively). For completing Koch's postulates, $C$. seifrizii plants were inoculated by spraying spore suspension $\left(1 \times 10^{6}\right.$ spores $\left./ \mathrm{ml}\right)$, while

Imran Ul haq

Imran_1614@yahoo.com

1 Department of Plant Pathology, University of Agriculture, Faisalabad, Punjab, Pakistan

2 Centre of Agricultural Biochemistry and Biotechnology, University of Agriculture Faisalabad, Punjab, Pakistan control plants were treated with sterile distilled water only and covered with polythene bags during first $24 \mathrm{~h}$ to keep them moist for disease development (Kittimorakul et al. 2013). The symptoms appeared on inoculated plants after three weeks and they were similar at field symptoms, while control plants were symptomless. A reference isolate of $C$. lunata was deposited to Fungal Molecular Biology Culture Collection University of Agriculture Faisalabad, Pakistan (FMB-CC-UAF) with culture collection number FMB0200. To the best of our knowledge, this is the first report of $C$. lunata causing leaf spot on $C$. seifrizii in Pakistan and worldwide (Farr and Rossman 2020).

Funding This study was funded by HEC Project \#2762.

\section{Declarations}

Ethical statement This article does not contain any studies with human participants or animals.

Conflict of interest All authors declare that they have no conflict of interests.

\section{References}

Farr DF, Rossman AY (2020) Fungal Databases, U.S. National Fungus Collections, ARS, USDA. Retrieved 28 Dec 2020

Kittimorakul J, Chaninun P, Anurag S, Vasun P (2013) Survey and incidence of leaf blight and leaf spot diseases of oil palm seedlings in Southern Thailand. Plant Path J 12(3):149-215

Manamgoda DS, Cai L, McKenzie EH, Crous PW, Madrid H, Chukeatirote E, Shivas RG, Tan YP, Hyde KD (2012) A phylogenetic and taxonomic re-evaluation of the Bipolaris- Cochliobolus-Curvularia complex. Fungal Divers 56(1):131-144

Publisher's Note Springer Nature remains neutral with regard to jurisdictional claims in published maps and institutional affiliations. 